\title{
The Impact of Therapeutic Recreational Gymnastic Exercise on Basic Motor Skills of Hearing-Impaired Children Aged Between 6 and 9 Years
}

\author{
Nurcan Demirel \\ Correspondence: Atatürk University, Faculty of Sport Sciences, Department of Sport Health Sciences, Erzurum, Turkey.
}

Received: January 30, 2018

doi:10.11114/jets.v6i3.3048

\author{
Accepted: February 11, $2018 \quad$ Online Published: February 22, 2018 \\ URL: https://doi.org/10.11114/jets.v6i3.3048
}

\begin{abstract}
Purpose: The purpose of the current study is to investigate the impact of therapeutic recreational gymnastic exercises on basic motor skills of hearing-impaired children aged between 6-9 years.

Material and Method: 18 students (12 boys; 6 girls) between the ages of 6-9 years participated in the study. 9 of these students were determined as experimental group ( 3 girls; 6 boys), and the other 9 were determined as control group ( 3 girls; 6 boys). Before and after the trainings, gross motor development tests (25m. walking, running, jumping, gallop jumping, standing long jump, dribbling, throwing tennis ball, catching the thrown ball, kicking the thrown ball, kicking the still ball) were applied to all the students in the experimental and control group, and the data were recorded. "Special movement training programme" was prepared for the trainings. The trainings were performed for 50-75 minutes twice a week for ten weeks. After the ten-week training programme, gross motor development tests were reapplied to the children as post-test.
\end{abstract}

Analysis: The obtained data were analysed using SPSS.20, and of frequency, arithmetic mean and nonparametric tests, Mann Whitney U- test was applied as analysis method and the findings were tabulated.

Results and Discussion: As a result of the study, significant developments $(\mathrm{p}>0,01)$ were found in gross motor development tests $(25 \mathrm{~m}$. walking, jumping, gallop jumping, standing long jump, throwing tennis ball, catching the thrown ball, kicking the still ball) of the children in the control group. Positive developments were not observed in the tests of $25 \mathrm{~m}$. running, standing dribbling, kicking the thrown ball, and no significant developments ( $>>0,01$ ) were observed in children in the control group.

Keywords: hearing-impaired, educational games, football, gross motor development

\section{Introduction}

In terms of physical fitness, hearing-impaired children among the disabled are not different from those who have no hearing problem. Some differences based on age and gender were observed in performance (Özer, 2001). Social and emotional development of hearing-impaired children follows a basic pattern, similar to their hearing peers. At earlier ages, the communication difference of hearing-impaired children is not an obstacle for the games with their hearing peers. The can play games together and can develop their friendship (Ataman, 2003).

\section{Relevant Literature}

It is an undeniable fact that when disabled individuals are motivated for sports, their process of fitting into society accelerates and at the same time positive developments in their physical and physiological capacities are observed. The problems faced by the disabled do not only belong to them but also to their families, friends and every single individual in the society. There are a number of studies asserting that the static and dynamic balance skills of hearing-impaired children can be affected depending on their age, gender, etiology, and hearing loss degree. The fact that the loss of balances (static and dynamic) is more in hearing-impaired children significantly affects their daily life (Siegel, Marchetti \& Tecklin, 1991; Butterfield \& Ersing, 1986). The IQ level of most hearing-impaired children are at the same level as general population. Hearing loss impairs speech development of the children. Hearing-impaired children have difficulties in speech and language development and especially in academic skills such as reading and writing. Generally, there is not a cognitive problem. However, a number of factors such as the type and degree of hearing loss; the age of the hearing loss; mental development of the child; the attitudes of the child and people around him/her towards the inability affect arising these problems and their degrees (Diken, 2011). 
Hearing-impaired children go through the same developmental process as their hearing peers at the ages of $0-2$ years. However, at later ages, delay and inefficiency can be observed in skills related to balance and body coordination due to the defects in auditory canal nerves of hearing-impaired children (Ersoy \& Avc1, 2000). It was found in the studies with children aged between 6-10 years that hearing-impaired children were less successful in fine motor skills than their hearing peers (Levis, 1992; Güven \& Bal, 1992; Baldemir \& Bal, 1995; Darıca \& Tanju, 1995; Erdem \& Otman, 1996; Bal \& Tanju, 1997). What is the purpose of the current study?

The purpose of the current study is to investigate the impact of therapeutic recreational gymnastic exercises on basic motor skills of hearing-impaired children aged between 6-9 years.

\section{Methods}

\subsection{Participants and Procedure}

18 students (12 boys; 6 girls) between the ages of 6-9 years participated in the study. 9 of these students were experimental group ( 3 girls; 6 boys), and the other 9 were control group ( 3 girls; 6 boys). Permission was granted for the study by Erzurum Directorate of National Education, the school administrators and the families of the participants. Before the trainings, gross motor development tests $(25 \mathrm{~m}$. walking, $25 \mathrm{~m}$. running, jumping, gallop jumping, standing long jump, standing dribbling, throwing tennis ball, catching the thrown ball, kicking the thrown ball, kicking the still ball) were applied to all the students in the experimental and control group, and the data were recorded. "Special movement training programme" was prepared for the trainings. The trainings were performed for 50-75 minutes twice a week for ten weeks. Volunteer students from the Department of Recreation, Faculty of Sport Sciences, supported the study. These volunteers were chosen from the students who took "Physical Education and Sport for the Disabled", course and "Therapeutic Recreation and Programme Development in Recreation Services" course. After the ten-week training programme, gross motor development tests were reapplied to the children as post-test.

The following materials were prepared for the study:

1. Barriers of different heights $(10 \mathrm{~cm} ., 15 \mathrm{~cm} ., 20 \mathrm{~cm} ., 25 \mathrm{~cm}$., and $30 \mathrm{~cm}$.)

2. Balls of different sizes (basketball, volleyball, $\mathrm{f}$ balls)

3. Health balls in different weights $(1 \mathrm{~kg} ., 1.5 \mathrm{~kg} ., 2 \mathrm{~kg}$.)

4. Pilates balls of different sizes $(30 \mathrm{~cm} ., 40 \mathrm{~cm} ., 50 \mathrm{~cm}$., and $70 \mathrm{~cm}$.)

5. Jumping rope (rubber, rope)

6. Balance boards of different heights $(20 \mathrm{~cm}, 30 \mathrm{~cm}$, and $40 \mathrm{~cm}$.)

7. Towing rope ( $3 \mathrm{~m} ., 5 \mathrm{~m} ., 7 \mathrm{~m}$.)

8. Exercise springs (rubber bands)

9. Mini trampoline (diameter $100 \mathrm{~cm}$., diameter $125 \mathrm{~cm}$.)

10. Ball targets of different sizes (height $150 \mathrm{~cm} ., 175 \mathrm{~cm}$. , and $200 \mathrm{~cm}$.) 


\subsection{Special Movement Training Programme}

Table 1. Special movement training programme applied in the study

\begin{tabular}{|c|c|c|c|c|}
\hline Weeks & Days & Purpose & Content & Gains \\
\hline \multirow[t]{2}{*}{1} & Sat. & Walking, running, leaping & $\begin{array}{l}\text { Straight walking, slalom walking, straight running, } \\
\text { slalom running, standing leaping, leaping while } \\
\text { walking }\end{array}$ & $\begin{array}{l}\text { To be able to walk in balance, to run and } \\
\text { to leap }\end{array}$ \\
\hline & Sun. & Holding, gripping, throwing & $\begin{array}{l}\text { Holding, gripping and throwing the ball, holding, } \\
\text { gripping and throwing the tennis ball }\end{array}$ & $\begin{array}{l}\text { To be able to hold the objects properly, } \\
\text { to grip, to throw }\end{array}$ \\
\hline \multirow[t]{2}{*}{2} & Sat. & Walking, running, leaping & $\begin{array}{l}\text { Straight walking, slalom walking, straight running, } \\
\text { slalom running, standing leaping, leaping while } \\
\text { walking }\end{array}$ & $\begin{array}{l}\text { To be able to walk in balance, to run and } \\
\text { to leap }\end{array}$ \\
\hline & Sun. & Holding, gripping, throwing & $\begin{array}{l}\text { Holding, gripping and throwing the ball, holding, } \\
\text { gripping and throwing the tennis ball }\end{array}$ & $\begin{array}{l}\text { To be able to walk in balance, to run and } \\
\text { to leap }\end{array}$ \\
\hline \multirow[t]{2}{*}{3} & Sat. & $\begin{array}{l}\text { Holding and throwing, holding } \\
\text { with foot and kicking, throwing } \\
\text { to the target }\end{array}$ & $\begin{array}{l}\text { Catching the thrown ball an rethrowing, holding } \\
\text { the rolling ball with foot and kicking, throwing and } \\
\text { kicking the ball to the target }\end{array}$ & $\begin{array}{l}\text { To be able to hold the balls in different } \\
\text { size and weight with both hands and } \\
\text { feet, to control and to throw }\end{array}$ \\
\hline & Sun. & $\begin{array}{l}\text { Throwing and kicking the ball } \\
\text { to the target }\end{array}$ & $\begin{array}{l}\text { Throwing the ball to the target, Throwing the } \\
\text { tennis ball to the target, kicking the soccer ball to } \\
\text { the target }\end{array}$ & $\begin{array}{l}\text { To be able to hold the balls in different } \\
\text { size and weight with both hands and } \\
\text { feet, to control and to throw }\end{array}$ \\
\hline \multirow[t]{2}{*}{4} & Sat. & $\begin{array}{l}\text { Holding and throwing, holding } \\
\text { with foot and kicking, throwing } \\
\text { to the target }\end{array}$ & $\begin{array}{l}\text { Catching the thrown ball an rethrowing, holding } \\
\text { the rolling ball with foot and kicking, throwing and } \\
\text { kicking the ball to the target }\end{array}$ & $\begin{array}{l}\text { To be able to hold the balls in different } \\
\text { size and weight with both hands and } \\
\text { feet, to control and to throw }\end{array}$ \\
\hline & Sun. & $\begin{array}{l}\text { Throwing and kicking the ball } \\
\text { to the target }\end{array}$ & $\begin{array}{l}\text { Throwing the ball to the target, Throwing the } \\
\text { tennis ball to the target, kicking the soccer ball to } \\
\text { the target }\end{array}$ & $\begin{array}{l}\text { To be able to hold the balls in different } \\
\text { size and weight with both hands and } \\
\text { feet, to control and to throw }\end{array}$ \\
\hline \multirow[t]{2}{*}{5} & Sat. & $\begin{array}{l}\text { Rolling, climbing, walking in } \\
\text { balance, hopping }\end{array}$ & $\begin{array}{l}\text { Rolling on a flat gym mat, climbing up a gym mat, } \\
\text { walking during gymnastics, hopping on the rope } \\
\text { ladder on one foot and both feet }\end{array}$ & $\begin{array}{l}\text { To be able to roll properly and in } \\
\text { balance, to climb, to walk in balance, to } \\
\text { hop }\end{array}$ \\
\hline & Sun. & $\begin{array}{l}\text { Rolling, climbing, walking in } \\
\text { balance, hopping }\end{array}$ & $\begin{array}{l}\text { Rolling on inclined mat, climbing up inclined mat, } \\
\text { walking during gymnastics, hopping on the rope } \\
\text { ladder on one foot and both feet }\end{array}$ & $\begin{array}{l}\text { To be able to roll properly and in } \\
\text { balance, to climb, to walk in balance, to } \\
\text { hop }\end{array}$ \\
\hline \multirow[t]{2}{*}{6} & Sat. & $\begin{array}{l}\text { Rolling, climbing, walking in } \\
\text { balance, hopping }\end{array}$ & $\begin{array}{l}\text { Rolling on a flat gym mat, climbing up a gym mat, } \\
\text { walking during gymnastics, hopping on the rope } \\
\text { ladder on one foot and both feet }\end{array}$ & $\begin{array}{l}\text { To be able to roll properly and in } \\
\text { balance, to climb, to walk in balance, to } \\
\text { hop }\end{array}$ \\
\hline & Sun. & $\begin{array}{l}\text { Rolling, climbing, walking in } \\
\text { balance, hopping }\end{array}$ & $\begin{array}{l}\text { Rolling on inclined mat, climbing up inclined mat, } \\
\text { walking during gymnastics, hopping on the rope } \\
\text { ladder on one foot and both feet }\end{array}$ & $\begin{array}{l}\text { To be able to roll properly and in } \\
\text { balance, to climb, to walk in balance, to } \\
\text { hop }\end{array}$ \\
\hline \multirow[t]{2}{*}{7} & Sat. & $\begin{array}{l}\text { Dribbling, shooting, passing in } \\
\text { basketball }\end{array}$ & $\begin{array}{l}\text { Training with the techniques specific to the sport } \\
\text { branch }\end{array}$ & $\begin{array}{l}\text { To be able to perform technique skills } \\
\text { specific to the sport branches }\end{array}$ \\
\hline & Sun. & $\begin{array}{l}\text { Dribbling, shooting, passing in } \\
\text { football }\end{array}$ & $\begin{array}{l}\text { Training with the techniques specific to the sport } \\
\text { branch }\end{array}$ & $\begin{array}{l}\text { To be able to perform technique skills } \\
\text { specific to the sport branches }\end{array}$ \\
\hline \multirow[t]{2}{*}{8} & Sat. & $\begin{array}{l}\text { Dribbling, shooting, passing in } \\
\text { basketball }\end{array}$ & $\begin{array}{l}\text { Training with the techniques specific to the sport } \\
\text { branch }\end{array}$ & $\begin{array}{l}\text { To be able to perform technique skills } \\
\text { specific to the sport branches }\end{array}$ \\
\hline & Sun. & $\begin{array}{l}\text { Dribbling, shooting, passing in } \\
\text { football }\end{array}$ & $\begin{array}{l}\text { Training with the techniques specific to the sport } \\
\text { branch }\end{array}$ & $\begin{array}{l}\text { To be able to perform technique skills } \\
\text { specific to the sport branches }\end{array}$ \\
\hline \multirow[t]{2}{*}{9} & Sat. & $\begin{array}{l}\text { Sports educational games, team } \\
\text { work }\end{array}$ & $\begin{array}{l}\text { Training with the educational games specific to the } \\
\text { sport branches }\end{array}$ & $\begin{array}{l}\text { To be able to hold the balls in different } \\
\text { size and weight with both hands and } \\
\text { feet, to control and to throw }\end{array}$ \\
\hline & Sun. & $\begin{array}{l}\text { Sports educational games, team } \\
\text { work }\end{array}$ & $\begin{array}{l}\text { Training with the educational games specific to the } \\
\text { sport branches }\end{array}$ & $\begin{array}{l}\text { To be able to roll properly and in } \\
\text { balance, to climb, to walk in balance, to } \\
\text { hop }\end{array}$ \\
\hline \multirow[t]{2}{*}{10} & Sat. & $\begin{array}{l}\text { Sports educational games, team } \\
\text { work }\end{array}$ & $\begin{array}{l}\text { Training with the educational games specific to the } \\
\text { sport branches }\end{array}$ & $\begin{array}{l}\text { To be able to perform technique skills } \\
\text { specific to the sport branches }\end{array}$ \\
\hline & Sun. & $\begin{array}{l}\text { Sports educational games, team } \\
\text { work }\end{array}$ & $\begin{array}{l}\text { Training with the educational games specific to the } \\
\text { sport branches }\end{array}$ & $\begin{array}{l}\text { To be able to play games in pairs and } \\
\text { groups, to obey the rules }\end{array}$ \\
\hline
\end{tabular}

\section{Data Analyses}

The obtained data were analysed using SPSS.20, and frequency, arithmetic mean and Wilcoxon signed-rank test were applied as analysis method and the findings were tabulated. 


\section{Discussion of the Results}

Table 2. The age, gender and grades of the participants

\begin{tabular}{|c|c|c|c|}
\hline GENDER & Group & $\mathbf{N}$ & $\%$ \\
\hline \multirow[t]{2}{*}{ Male } & Experimental & 6 & 33,3 \\
\hline & Control & 6 & 33,3 \\
\hline \multirow[t]{2}{*}{ Female } & Experimental & 3 & 16,6 \\
\hline & Control & 3 & 16,6 \\
\hline AGE & & $\mathbf{N}$ & $\%$ \\
\hline \multirow[t]{2}{*}{6 years } & Experimental & 2 & 5,5 \\
\hline & Control & 2 & 5,5 \\
\hline \multirow[t]{2}{*}{7 years } & Experimental & 3 & 11,1 \\
\hline & Control & 3 & 11,1 \\
\hline \multirow[t]{2}{*}{8 years } & Experimental & 2 & 8,3 \\
\hline & Control & 2 & 8,3 \\
\hline \multirow[t]{2}{*}{9 years } & Experimental & 2 & 5,5 \\
\hline & Control & 2 & 5,5 \\
\hline GRADE & & $\mathbf{N}$ & $\%$ \\
\hline \multirow[t]{2}{*}{$5^{\text {th }}$ grade } & Experimental & 2 & 16,6 \\
\hline & Control & 2 & 16,6 \\
\hline \multirow[t]{2}{*}{$6^{\text {th }}$ grade } & Experimental & 3 & 13,8 \\
\hline & Control & 3 & 13,8 \\
\hline \multirow[t]{2}{*}{$7^{\text {th }}$ grade } & Experimental & 2 & 11,1 \\
\hline & Control & 2 & 11,1 \\
\hline \multirow[t]{2}{*}{$8^{\text {th }}$ grade } & Experimental & 2 & 8,3 \\
\hline & Control & 2 & 8,3 \\
\hline
\end{tabular}

Table 3. The pre-test and post-test scores of the experimental group

\begin{tabular}{lllll}
\hline Applied Tests & $\begin{array}{l}\text { Pre-test } \\
\text { X } \pm \text { S.D }\end{array}$ & $\begin{array}{l}\text { Post-test } \\
\text { X } \pm \text { S.D }\end{array}$ & Z & $\begin{array}{l}\text { Significance } \\
\text { Level }\end{array}$ \\
\hline 25 m. walking & $5,21 \mathrm{sn}$. & 4,33 & $-7,615$ &, $001 * * *$ \\
25 m. running & $4,75 \mathrm{sn}$. & 4,65 & 2,256 &, 975 \\
Jumping & $18,35 \mathrm{~cm}$. & 27,45 & $-13,186$ &, $001 * * *$ \\
Galop jumping & $45 \mathrm{~cm}$. & 65 & $-3,079$ &, $001 * * *$ \\
Standing long jump & $65 \mathrm{~cm}$. & 95 & $-8,417$ &, $001 * * *$ \\
Standing dribbling & $6 \mathrm{sn}$. & $5 \mathrm{~s}$. & 1,925 &, 619 \\
Throwing tennis ball & $15,45 \mathrm{~m}$. & 25,35 & $-10,935$ &, $001 * * *$ \\
Catching the thrown ball & 3 in 5 & 5 in 5 & $-10,944$ &, $001 * * *$ \\
Kicking the thrown ball & 2 in 5 & 2 in 5 & 4,540 &, 575 \\
Kicking the still ball & $12 \mathrm{~m}$. & $20 \mathrm{~m}$. & $-8,345$ &, $001^{* * *}$ \\
\hline
\end{tabular}

Table 4. The pre-test and post-test scores of the control group

\begin{tabular}{lllll}
\hline Applied Tests & $\begin{array}{l}\text { Pre-test } \\
\text { X }\end{array}$ & $\begin{array}{l}\text { Post-test } \\
\text { X } \pm \text { S.D }\end{array}$ & Z & $\begin{array}{l}\text { Significance } \\
\text { Level }\end{array}$ \\
\hline 25 m. walking & $5,45 \mathrm{sn}$. & 5,33 & $-4,615$ &, 565 \\
25 m. running & $5,75 \mathrm{sn}$. & 5,65 & $-2,256$ &, 975 \\
Jumping & $16,30 \mathrm{~cm}$. & 17,45 & $-3,186$ &, 735 \\
Galop jumping & $40 \mathrm{~cm}$. & 45 & $-3,079$ &, 235 \\
Standing long jump & $55 \mathrm{~cm}$. & 55 & $-5,417$ &, 127 \\
Standing dribbling & $7 \mathrm{sn}$. & $6 \mathrm{sn}$. & $-1,925$ &, 619 \\
Throwing tennis ball & $17,50 \mathrm{~m}$. & 18,50 & $-6,935$ &, 895 \\
Catching the thrown ball & 5 in 3 & 5 te 2 & $-4,944$ &, 456 \\
Kicking the thrown ball & 5 in 2 & 5 te 2 & $-4,540$ &, 575 \\
Kicking the still ball & $10 \mathrm{~m}$. & $11 \mathrm{~m}$. & $-6,345$ &, 295 \\
\hline
\end{tabular}

As a result of the study, significant developments $(p>0,01)$ were found in gross motor development tests $(25 \mathrm{~m}$. walking, jumping, gallop jumping, standing long jump, throwing tennis ball, catching the thrown ball, kicking the still ball) of the children in the experimental group. Positive developments were not observed in the tests of $25 \mathrm{~m}$. running, standing dribbling, kicking the thrown ball. No significant developments $(p>0,01)$ were observed in children in the control group.

In previous studies about hearing-impaired children, it was asserted that there were developments parallel with the age in running, throwing, hitting and hopping, but there were delays in kicking the ball, leaping, catching and jumping.

Some researchers observed delays in bouncing the ball, catching, kicking the ball, and throwing the ball among the hearing-impaired children. In another study (Winnick \& Short, 1985), it was found that motor performance of the hearing-impaired students who went to a school for hearing-impaired children was significantly higher than of those who went to a public school with inclusive education. Exercise programmes prepared for and applied to 
hearing-impaired children are more effective on improving the vestibular deficits (balance, coordination, etc.) of the children (Rajendran, Roy \& Jeevanantham, 2013).

According to general clinical findings, significant motor skills deficits were observed in hearing-impaired children compared to their peers. This rate can reach to $80 \%$. In partially hearing-impaired children, this rate is almost $50 \%$ (Livingstone \& Mc Phillips, 2011).

\section{Conclusion and Recommendations}

Considering the results of the present study, it can be said that exercise and movement training programmes for hearing-impaired made positive contributions to the motor skills of the children. It is believed that special movement training programmes prepared for hearing-impaired individuals (educational games, various sport activities, mounting climbing and trekking, athletics, etc.) will make a great contribution to psychomotor development of the children.

\section{References}

Ataman, A. (2003). Özel Gereksinimi Olan Çocuklar ve Özel Eğitim. A. Ataman (Editör), Özel Eğitime Giriş. Ankara: Gündüz Eğitim ve Yayıncllı.

Avcı, N., \& Ersoy, Ö. (2000). Özel Gereksinimi Olan Çocuklar ve Eğitimleri Özel Eğitim. Ya-pa Yayıncllı, İstanbul, Ekim.

Bal, S., \& Tanju, E. (1997). Motor skills development of hearing impaired children and supportive activities, 11 . Antalya-International Symposium on Sport Education of the Disabled. 7-9 November, Antalya.

Baldemir, A., \& Bal, S. (1995). An analysis of motor skills of individuals with severe hearing loss between the ages of 37-42, Antalya International Symposium on Sport Education of the Disabled. 26-28 October, Antalya.

Butterfield, S. A., \& Ersing, W. F. (1986). Influence of Age, Sex, Etiology, and Hearing Loss on Balance Performance by Deaf Children. Perceptual and Motor Skills, 62(2), 659-663. https://doi.org/10.2466/pms.1986.62.2.659

Darıca, N., \& Tanju, E. (1995). Hearing impaired children and motor skills development. Antalya International Symposium on Sport Education of the Disabled, 26-28 October, Antalya.

Diken, İ. H. (2011). Otistik Bozukluğu Olan Öğrenciler. (Ed.) Diken, İH Özel Eğitime Gereksinimi Olan Öğrenciler ve Özel Eğitim. Ünite, 13, 409-447.

Erdem, Z., \& Otman, A. S. (1996). A Comparison of Motor Functions Between Hearing Impairedand Healty Children, The Deafened and the Born Deaf. April, Antalya.

Güven, N., \& Bal, S. (1992). Motor skills development of big muscles of hearing and hearing impaired children and education, Fizyoterapi Rehabilitasyon, (2).

Lewis, V. (1992). Development nd Handicap. Oxfort: Blackwell Publishers, England, S.60-81.

Livingstone, N., \& Mcphillips, M. (2011). Motor Skill Deficits in Children with Partial Hearing. Developmental Medicine \& Child Neurology, 53(9), 836-842. https://doi.org/10.1111/j.1469-8749.2011.04001.x

Özer, D. S. (2001). Engelliler İçin Beden Eğitimi ve Spor. Nobel Yayın Dağıtım, Ankara.

Rajendran, V., Roy, F. G., \& Jeevanantham, D. (2013). Effect of Exercise Intervention on Vestibular Related Impairments in Hearing-Impaired Children. Alexandria Journal of Medicine, 49(1), 7-12.

https://doi.org/10.1016/j.ajme.2012.10.001

Siegel, J. C., Marchetti, M., \& Tecklin, J. S. (1991). Age-Related Balance Changes in Hearing-Impaired Children. Physical Therapy, 71(3), 183-189.

Winnick, J. P., \& Short, F. X. (1985). Physical Fitness Testing of the Disabled: Project UNIQUE. Human Kinetics, 165.

\section{Copyrights}

Copyright for this article is retained by the author(s), with first publication rights granted to the journal.

This is an open-access article distributed under the terms and conditions of the Creative Commons Attribution license which permits unrestricted use, distribution, and reproduction in any medium, provided the original work is properly cited. 